\title{
Andrzej Nikitorowicz*
}

Wyższa Szkoła Administracji Publicznej w Białymstoku

\section{KIERUNKI AKTYWNOŚCI MNIEJSZOŚCI NARODOWYCH W WARUNKACH DEMOKRACJI NA PRZYKŁADZIE MNIEJSZOŚCI UKRAIŃSKIEJ W WOJEWÓDZTWIE PODLASKIM ${ }^{1}$}

\begin{abstract}
W artykule zamierzam skrótowo przedstawić podstawowe kierunki działań mniejszości narodowej w warunkach demokracji, odnosząc się do badań własnych nad mniejszością ukraińską w województwie podlaskim. Podobnie jak w warunkach ustrojów autokratycznych także w warunkach demokratycznych nie jest oczywiste antycypowanie dalszych przeobrażeń mniejszości narodowych. Zakładam, że podstawowe kierunki aktywności zbiorowości jako całości dotyczą przede wszystkim jej kontaktów z większością narodową i wywodzących się stąd trzech dróg. Zawsze, gdy jest mowa o mniejszości, automatycznie bierzemy pod uwagę większość, która ją otacza i niejako jest niezbędna przy określaniu świadomości i tożsamości mniejszościowej. W tej sytuacji rzeczą równie naturalną i występującą powszechnie jest kontakt kulturowy między mniejszością i większością, rozumiany jako następstwo spotkania się przedstawicieli grup czy zbiorowości reprezentujących odmienne kultury. Generalnie podejmowane kontakty powodują, że mniejszość narodowa może ulegać procesom asymilacji, integracji lub dalszej autonomizacji, a nawet separacji od większości. W ramach tych trzech procesów mniejszość podejmuje wiele działań, aby te procesy stały się możliwe lub jak w przypadku asymilacji przez większość podejmuje działania mające na celu zapobieganie im.
\end{abstract}

Kontakty z przedstawicielami odmiennych kultur umożliwiały i umożliwiają pojawianie się granic w tożsamości, poczucia odrębności i przynależności do danej grupy. Znaczenie „obcych” przy konstruowaniu obrazu samego siebie i własnej grupy podkreślali m.in. A. Kłoskowska (1992a, 1992b), J. Obrębski (2005) i E. Nowicka (1990).

Kontakty pomiędzy mniejszością a większością w sytuacji demokratyzacji życia społecznego i politycznego oraz pluralizmu kulturowego mogą przybierać różne postaci i ewoluować w całkowicie odmiennych kierunkach. W artykule chciałbym zająć się tymi kierunkami procesów mniejszościowo-większościowych, które w największym stopniu dotyczą i mogą

* Adres do korespondencji: Andrzej Nikitorowicz, Wyższa Szkoła Administracji Publicznej w Białymstoku, ul. Księdza Stanisława Suchowolca 6, 15-567 Białystok, e-mail: andniki@wp.pl.

1 Niniejszy tekst związany jest z realizacją projektu Procesy tworzenia się (konstruowania) matego narodu (kulturowego) na przykładzie obiegowo nazywanej mniejszości ukraińskiej w województwie podlaskim finansowanego przez Narodowe Centrum Nauki w Krakowie, realizowanego przez autora niniejszego tekstu (umowa nr UMO-2011/01/N/HS6/05014 do wniosku nr 2011/01/n/HS6/05014). 
dotyczyć w przyszłości badanej przeze mnie mniejszości ukraińskiej w województwie podlaskim. Szerzej teoretyczne podstawy tych procesów opisane zostały w monografii powstałej na podstawie przedstawionych $\mathrm{w}$ artykule badań (Nikitorowicz 2014).

Obecnie szczególnie powinny nas interesować różne skutki współwystępowania i wzajemnego postrzegania się mniejszości i większości narodowych. Żyjemy bowiem w świecie zmiennym, dynamicznym, nieprzewidywalnym, w świecie, w którym obok tradycyjnego pogranicza stykowego i przejściowego, bezpośrednich i pośrednich kontaktów ludności zakorzenionej na danym terytorium, mamy wiele różnych sposobności kontaktów z innymi powstałych jako efekt przemieszczania się (uchodźctwa, migracji), otwarcia granic, migracji ekonomicznych, ciekawości innych kultur itp. Demokratyzacja świata umożliwiła wielu mniejszościom, a w szczególności mniejszościom narodowym i etnicznym upomnienie się o swoje prawa i miejsce w strukturze danych społeczeństw i państw. Większość dominująca w danym państwie nie zawsze reaguje w sposób przyjazny albo przynajmniej obojętny w stosunku do fenomenu odradzania się i rewitalizacji kultury grup mniejszościowych. Paweł Boski(Boski 2008: 165-205), przywołując prace Johna Berrego, przedstawia cztery modele strategii akulturacyjnych na poziomie polityki i praktyki władz państwowych:

1) Wylączanie - wykluczenie, czystki etniczne (exclusion), czyli eliminowanie obecności mniejszości na wspólnym obszarze przez wysiedlenia, wypędzenia, deportacje, ludobójstwo itp.

2) Segregacja - separacja, czyli określenie i realizowanie odrębnych ścieżek rozwojowych różnych ras, grup etnicznych, religijnych zamieszkujących dane społeczeństwo, przy utrzymaniu dominacji jednej grupy.

3) Tygiel etniczny - republika obywateli, czyli usuwanie różnorodności w zdążaniu do homogenizacji etnicznej. „Polityka tygla etnicznego oznacza relatywne otwarcie na odmienność etniczną, przy założeniu, że imigranci możliwie szybko przemienią się w obywateli nowego kraju, odcinając swe więzy z krajem przodków” (Boski 2008: 169).

4) Wielokulturowość, czyli promowanie intensywnych relacji między odmiennymi grupami przy jednoczesnym zachowaniu tożsamości każdej z nich. W tym przypadku odmienność i różnorodność są afirmowane, gdyż każda z kultur ma do zaoferowania innym określone wartości.

Powyższym wariantom makrospołecznych działań państwa i grup większościowych odpowiadają reakcje jednostek i grup mniejszościowych związane z utrzymaniem dziedzictwa kultury pochodzenia i tożsamości etnicznej:

1) Marginalizacja odpowiada systemowemu wykluczeniu i oznacza wycofanie się poza obszar kultury, wejście do podkultury marginesu społecznego, co najczęściej jest związane $\mathrm{z}$ nieudaną akulturacją.

2) Separacja jest odgrodzeniem się jednostki lub grupy od wpływów nowego i obcego środowiska i zorganizowaniem życia w ramach swej dotychczasowej grupy etnicznej, co ma miejsce w wielkich aglomeracjach skupiających liczne grupy emigrantów we Francji, Niemczech, USA, Wielkiej Brytanii.

3) Asymilacja oznacza rezygnację z kultury pochodzenia, odcięcie więzów z krajem pochodzenia przodków i pełne wejście w obszar drugiej kultury. 
4) Integracja jest konsekwencją wielokulturowości, realizowanych programów rządowych, które sprzyjają i zachęcają do utrzymywania kultury rodzimej - kultury pochodzenia oraz nabywania i konstruowania nowej tożsamości kultury osiedlenia.

Hieronim Kubiak pisze, że w socjologii ,(...) asymilacja odnoszona jest przede wszystkim do stosunków międzygrupowych, a zwłaszcza między imigrantami a społeczeństwem przyjmującym oraz między wspólnotami kulturowymi (językowymi, religijnymi) nieposiadającymi własnego państwa narodowego a wspólnotami, które mają własne państwo" (Kubiak 2005: 31). Kontekstem i przestrzenią społeczna, w której przebiega asymilacja, są stałe i bezpośrednie kontakty między grupami o różnym etnosie. Asymilacja prowadzi zarówno do wymiany, jak i dyfuzji, nie ma i nie może mieć jednak charakteru wielokierunkowej zmiany kulturowej, jest zawsze procesem jednokierunkowym, którego celem jest włączenie jednostek lub danej grupy w nurt życia i kultury grupy dominującej. W celu udanej i pełnej asymilacji konieczny jest również pozytywny stosunek reprezentantów grupy asymilującej się do wartości i kultury grupy większościowej, a z drugiej strony czynnikiem równie niezbędnym jest akceptacja przedstawicieli asymilującej się grupy mniejszościowej przez społeczną większość. Brak tej akceptacji powoduje, że asymilacja nie jest pełna i udana, gdyż przedstawiciele mniejszości w tym przypadku nie są w pełni włączani do życia społecznego większości asymilującej i nie mogą ostatecznie stać się jej pełnoprawnymi członkami. Bardzo często to właśnie ten ostatni element, czyli niepełne przyjęcie neofitów przez społeczeństwo asymilujące, powoduje niepełną asymilację mniejszości, a nawet powracanie do własnych tradycji, wartości, kultury i regres asymilacji (Piotrowski 1998; Posern-Zieliński 1999).

Asymilacja mniejszości jawi się więc jako długi proces nie zawsze kończący się na tym samym etapie, nie zawsze pełny, zależny od kontekstu społecznego i politycznego, w którym przebiega. Demokratyczne państwo prawa stwarza odmienne warunki dla przebiegu procesów asymilacyjnych. Inne jest tutaj podejście samych obywateli do wolności osobistej, postrzegania innych czy do zjawiska dyskryminowania przedstawicieli grup mniejszościowych.

Zmiana podejścia zwłaszcza do mniejszości narodowych czy etnicznych wynika z polityki samego państwa, które oficjalnie rezygnuje z forsowania asymilacji na rzecz innych form współdziałania, integracji, ze szczególnym uwzględnieniem pluralizmu kulturowego. W połowie lat dziewięćdziesiątych A. Sadowski tak pisał o asymilacji strukturalnej mniejszości w województwie podlaskim: „Asymilacja strukturalna oznacza procesy wejścia przedstawicieli mniejszości narodowej do formalnych i nieformalnych struktur społeczeństwa przyjmującego. Na etapie asymilacji strukturalnej mniejszość często bywa definiowana jako subkultura grupy dominującej, nie zaś jako mniejszość narodowa. Przedstawiciele mniejszości, którzy osiągnęli w strukturze większości narodowej wysokie pozycje społeczne i zawodowe, skłonni są do całkowitego zerwania kontaktów z grupa pochodzenia, ponieważ w subiektywnym przekonaniu przyznawanie się do partycypacji w kulturze wartościowanej negatywnie jako tradycyjna, może prowadzić do degradacji własnej wartości” (Sadowski 1995: 20).

W przypadku mniejszości ukraińskiej w województwie podlaskim jest to w większości do dzisiaj ludność o słabo wykształconej tożsamości etnicznej czy narodowej. Jako przedstawiciele grupy mniejszościowej o specyficznych cechach odróżniających ich od grupy dominującej w kraju (np. religia, język, tradycje) poddani zostali na przestrzeni wielu lat różnym klasyfikacjom narodowym. W związku z tym należy podkreślić, że w wielu przypadkach, jeśli 
nie w większości, przedstawiciele mniejszości nie protestowali, a raczej poddawali się narzucanym im odgórnie podziałom i klasyfikacjom. W przypadku Ukraińców w województwie podlaskim pojawia się problem nie tylko ich asymilacji przez polską większość, ale głównie asymilacji, a nawet inkorporacji tej ludności przez mniejszość białoruską w regionie. Kiedy władze państwowe silnie promowały stereotyp ,prawosławny to Białorusin”, wielu przyjęło te wskazówki tożsamościowe za prawidłowe i swoje. Dlatego „,...) aż 73\% deklaracji narodowości białoruskiej na Podlasiu przypada na obszar między Bugiem a Narwią, czyli na ziemie, które według historyków i językoznawców, zostały w średniowieczu zasiedlone przez ludność pochodzenia ukraińskiego (...)" (Barwiński 2011: 130). W związku z tym główna aktywność pierwszych świadomych Ukraińców w regionie koncentrowała się wokół zaprzeczenia białoruskości i budowy, poszukiwania własnej odrębnej tożsamości narodowo-etnicznej.

W przeprowadzonych przeze mnie badaniach (badania jakościowe własne przeprowadzone od 01.05.2011 do 31.06.2012, na próbie 54 osób deklarujących etniczne pochodzenie ukraińskie i zamieszkujących województwo podlaskie, dokładne wyniki w pracy doktorskiej Procesy tworzenia się (konstruowania) małego narodu (kulturowego) na przykładzie mniejszości ukraińskiej w województwie podlaskim oraz powstałej na jej podstawie monografii) wielu respondentów podkreślało fakt izolowania się ludności od wiedzy na temat własnej odrębności i długi proces przekłamywania historii, poszukiwań tożsamości, zaprzeczania białoruskości i otrzymania rzetelnych i prawdziwych argumentów dotyczących rzeczywistej tożsamości:

Dokładnie tak. Oczywiście że nie od zawsze się czułem Ukraińcem. Moja ukraińskość pojawiała się od zaprzeczania białoruskości, dlatego że ja jestem tym pierwszym pokoleniem, które że tak powiem dostało argumenty, żeby powiedzieć, że nas ordynarnie oszukują. Wmawiają nam ciemnotę, bo my tacy jesteśmy. Ja chyba miałem osiemnaście lat, jak wyszedł, pojawił się Atlas gwary Stowian wschodniej Białostocczyzny. Do tej pory gdzieś oficjalnie słyszałem tylko, że my rozmawiamy po białorusku. Wziąłem ten atlas gwar wschodniosłowiańskiej Białostocczyzny, czytam. I co tu się okazuje? Żaden to jest białoruski, tylko ukraiński. A była taka sytuacja, że byliśmy odcięci od szkoły, od literatury, od żywego słowa - kompletna izolacja. Ktoś tam chciał nas przekręcić jak w jakiejś maszynce. To się nie udało - na szczęście. To się właśnie zaczęło od zaprzeczania białoruskości, bo to nie była nasza tożsamość. No a później zaczęło się odkrywanie korzeni. Ta tożsamość zaczęła się, pojawiła się na drodze poszukiwań. Przy tych poszukiwaniach to chodziło mi o dobre samopoczucie i prawdę. Ja się źle z tym czułem, że mnie ktoś określał, że ja jestem Polakiem albo Białorusinem. Ja wcale tak nie uważałem, zacząłem poszukiwać ludzi, którzy myślą podobnie do mnie i się okazało, że nie jestem osamotniony, że jest nas sporo i z czasem zaczęliśmy tworzyć instytucje (W25).

Wielu badanych respondentów przyznawało się do uczestnictwa w ruchu białoruskim w województwie podlaskim, zanim ich aktywne działania doprowadziły do odnalezienia „,prawdziwej” tożsamości narodowej.

Na drodze poszukiwania korzeni, tutaj głównie ta droga. Podczas studiów byłem przez parę miesięcy i działałem w białoruskiej organizacji studenckiej. W tym okresie zacząłem dużo czytać książek na temat przynależności, tożsamości narodowej. Zacząłem szukać, jaki to jest język ten, którym się posługuję w domu i też w tym czasie, co było dla mnie ogromnym zaskoczeniem, rozpoczęły się dyskusje na ten temat w domu rodzinnym. I ojciec, który wcześniej o tym nie mówił, zaczął 
Kierunki aktywności mniejszości narodowych w warunkach demokracji...

wprost mówić, że jesteśmy Ukraińcami. Wujek, stryj też to potwierdzili. Dziadek zaczął też sam mówić, że on urodzony w 1900 roku, który przeżył wysiedlenie do Rosji i przeżył rewolucję październikową w Rosji, twierdził, że my jesteśmy Małorusinami, czyli to jest dawne określenie na Ukraińców. Także moje poszukiwania w literaturze fachowej zbiegły się z dyskusjami i poszukiwaniami w rodzinie i to dla mnie szybko stało się oczywiste. Zacząłem czytać też literaturę piękną ukraińską, bo też w Bielsku Podlaskim nie było takiej możliwości zakupu, ale na studiach w Warszawie pojawiły się piękne wydania tej literatury. I dla mnie stało się to oczywiste, że to jest mój język i mój naród (W4).

Potrzebę aktywnej walki i przeciwstawiania się białorutenizacji i oderwania miejscowej ludności od kultury białoruskiej podkreśla też najbardziej znany i znaczący głos Ukraińców Podlasia, czyli czasopismo „Nad Buhom i Narwoju”. W ramach promowanego dyskursu polityczno-ideologicznego często pojawiają się w nim artykuły dotyczące negatywnego postrzegania historii i asymilacji podlaskich Ukraińców oraz ich nieświadomości swojej prawdziwej narodowości i etniczności.

Działalność przedstawicieli mniejszości ukraińskiej w regionie, skierowana przeciwko asymilacji i procesom z nią związanym, prowadzona jest na dwa sposoby. Pierwszy wiąże się ze swoistym odkłamywaniem historii i uświadamianiem społeczności zamieszkującej między Bugiem i Narwią jej ukraińskich korzeni, natomiast drugi wiąże się z obroną ukraińskich gwar regionu oraz podkreślaniem ich ważności przy zaliczaniu danej ludności do konkretnego narodu.

Na Podlasiu terenem o największym odsetku ludności etnicznie ukraińskiej jest obszar kilku gmin pomiędzy Bielskiem a Hajnówką, a więc Orla, Dubicze Cerkiewne i Czyże. Jest to obszar typowo wiejski, gdzie w ciagu ostatniego stulecia nie powstały przyciągające ludność obcą ośrodki przemysłowe, jak to się stało w przypadku samej Hajnówki. Z drugiej strony właśnie tutaj, wg danych spisu powszechnego z 2002 roku, największy odsetek mieszkańców zadeklarował swoją narodowość jako białoruską, przy symbolicznej niemal ilości osób podających narodowość ukraińską. O przyczynach takiej sytuacji pisano już nie raz na łamach „Nad Buhom i Narwoju”. Głównie jest to rezultat wprowadzenia na Podlasiu po II wojnie światowej obowiązkowego nauczania języka białoruskiego (w wielu szkołach tych gmin przetrwało ono po dzień dzisiejszy) i zmonopolizowania życia kulturalnego przez BTSK, które przez swoje „fjaściny” budowało i nadal buduje wśród miejscowej ludności fałszywe przeświadczenie o jej białoruskiej przynależności narodowej. Sukcesywnie jednak monopol ten jest przełamywany i we wspomnianych gminach pojawiają się także inicjatywy ukraińskie, stanowiąc alternatywną propozycję dla mieszkańców (Filimoniuk 2005: 9).

W innym artykule odnoszącym się do spraw narodowościowych województwa podlaskiego możemy przeczytać, że większość świadomych Białorusinów w regionie tak naprawdę posługuje się gwarą ukraińską, a ich tożsamość została fałszywie ukształtowana w poprzednim systemie i niestety trwa do dzisiaj. „Największymi białoruskimi patriotami okazali się, co nie było dla nikogo niespodzianką - ukraińskojęzyczni mieszkańcy wsi i miasteczek między Bugiem i Narwią (...) Otóż Podlasze stanowią ok. 75\% ludności, która w naszym województwie podała narodowość białoruską i białoruski jako język używany w domu” (Dawidziuk 2005: 28). Wiele artykułów, podobnie jak ten cytowany, zaznacza skomplikowane relacje etniczne w regionie, potrzebę odwołania do badań lingwistów oraz odkłamania historii. „Asymilacja zbiera swoje żniwo, a Białorusini ukraińskojęzyczni mają prawo mieć swoją 
tożsamość, nawet jeżeli zbudowana była na manipulacjach i nieprawdzie. Ale na pewno różnice poglądów w środowisku białoruskim między Podlaszukami a Lićwinami oraz istnienie ruchu ukraińskiego wpłyną na część Podlasian poszukujących swej tożsamości. Nie tylko byli działacze białoruscy z Bielska Podlaskiego są Ukraińcami, jest wielu i w innych miejscowościach. Setki przykładów świadczą o tym, że fałszowanie historii jednak ma swój kres i mydlana bańka musi prysnąć" (Dawidziuk 2005: 29).

W dyskursie tworzonym przez Ukraińców Podlasia zaznacza się też wyraźna ideologiczna niechęć i walka o dusze między działaczami związku ukraińskiej i białoruskiej mniejszości w regionie. „Opinie wyrażone przez osoby uważane często za autorytety, znane szerokiej opinii publicznej w naszym regionie, a często i szerzej, mają chyba odwrócić uwagę od istoty problemu i przynajmniej częściowo przekonać, że Ukraińcy na Podlasiu są tylko obcym ciałem i - w zależności od autora - są albo szpiegami nasłanymi tu, aby rozwalać prężny i silny ruch białoruski, albo chłopami ledwo co wykształconymi, co to się wstydzą wiejskiego białoruskiego pochodzenia i chcą się podczepić pod bardziej atrakcyjny nurt ukraiński” (Dawidziuk 2005). Również w przeprowadzonych badaniach i wypowiedziach respondentów często pojawiał się wątek istotnych różnic w stosunku do mniejszości białoruskiej w województwie podlaskim oraz swoistej niechęci wobec działań białoruskiej organizacji.

To znaczy tak, że językowe różnice są szczególnie widoczne. Północ i południe Podlasia to szczególnie widać i da się łatwo rozpoznać. Działacze białoruscy bez sensu powtarzają to wszędzie, że jest język białoruski, a nie są to żadni naukowcy, ale proste i głupie poglądy. Ci ludzie działaja, mówią, ale nie konfrontują wiedzy z językoznawcami i przez to wprowadzają w błąd, kontynuują tą ułudę. Jeśli oni w to wierza, to ich sprawa, każdy ma prawo wierzyć, w co chce. Niektórzy działacze mówią, że to nie język ukraiński, ale starobiałoruski. Ja miałem w domu porównanie pomiędzy gwarą białoruską i ukraińską. Ja mam to z pierwszej ręki i wiem, jak jest, a oni wmawiają ciemnotę (W2).

Oczywiście kwestie językowe. Ludność ukraińska mówi po ukraińsku, a białoruska po białorusku. Są nieco inne zwyczaje. Na terenach etniczno-białoruskich występują pewne zwyczaje, które nie występują na terenie ukraińskim i na odwrót. Inna była też migracja tej ludności. Według badań naukowców, historyków, ludność ukraińska przybyła z południa, głownie z Wołynia czy z Ziemi Brzeskiej, a ludność białoruska z północno-wschodniej części, znad Niemna. Z tym że oczywiście ogromna grupa ludzi świadoma narodowo wszczęła czyn, która uważa się za Białorusinów, pochodzi z terenów etnicznie ukraińskich i stąd tutaj wychodzi duże zamieszanie. Często jest tak, że osoby, które etnicznie pochodzą z terenów ukraińskich, uważają się za Ukraińców lub częściej za Białorusinów i tutaj jest paradoks w tej sytuacji na Podlasiu (W4).

Aktywne działania pojawiają się również w związku z postrzeganiem etosu mniejszości ukraińskiej w województwie podlaskim oraz prowadzeniem działań na rzecz przekonania ludności do świadomego uczestnictwa w ruchu. W niektórych artykułach działacze ukraińscy próbują ustalić, jaka jest „baza demograficzna” ich ruchu na Podlasiu. Bazę tę wyznacza się na podstawie obiektywnych czynników przynależności etnicznej, w tym przypadku języka, kultury ludowej oraz religii. Autorzy są jednak świadomi, że dzisiaj na Podlasiu brak jest sprzężenia zwrotnego między tymi atrybutami ukraińskiej etniczności a świadomością i tożsamością mieszkańców tego obszaru. 
Kierunki aktywności mniejszości narodowych w warunkach demokracji...

W bieżącym roku mija dwadzieścia lat od momentu powstania Związku Ukraińców Podlasia, a także około czterdziestu od chwili, gdy młodzież ze wsi pomiędzy Bielskiem a Hajnówką sięgnęła po pióro, aby w ojczystym języku zapisać swoje myśli i emocje. Na dzień dzisiejszy ukraiński ruch kulturowy, który zaczął kształtować się w ostatnim ćwierćwieczu minionego tysiąclecia, ma pokaźną bazę demograficzną (...). Podsumowując, możemy stwierdzić, że obecnie województwo podlaskie zamieszkuje około 105-110-tysięczna rzesza osób mających ukraińskie korzenie etniczne i w większości utrzymujących jakieś formy związku z rodzimą tradycją - zachowując język ojczysty lub chociaż poczucie związku z prawosławiem (...). Tak więc proces kształtowania się ukraińskiej tożsamości narodowej wśród mieszkańców naszej podlaskiej „Mezopotamii” (międzyrzecza Bugu i Narwii), który rozpoczął się w latach 70-80. ub. wieku w sposób typowy dla tego typu procesów, a więc od prób literackich w języku rodzinnego domu, ma dość znaczne zaplecze demograficzne (Hawryluk 2012: 12).

W bardzo podobnym tonie odnośnie do etnosu, do którego mniejszość ukraińska w województwie podlaskim się odwołuje, wypowiada się duża część respondentów. Jeden z działaczy Związku Ukraińców Podlasia ujmuje te kwestie następująco:

My, związek jako społeczność, stoimy na stanowisku, że bardzo istotnym wyróżnikiem jest ta kultura tradycyjna, miejscowa i oczywiście język. Te kryteria dają jakieś podstawy do mówienia o tym, że jest to ludność ukraińska. Oczywiście tak jak zaznaczyłem wcześniej, są to osobiste wybory ludzi. Tutaj oczywiście gmatwa sprawę fakt taki, religii, a bardziej jeszcze to, że przez wiele lat uważano, że wszyscy prawosławni na Podlasiu to Białorusini i to wpajano ludziom. Ja myślę, że dzisiaj kierunkujemy się pracami językoznawców. Określają oni w miarę dokładnie wpływ osadnictwa wołyńskiego. Ogólnie są to ludzie zamieszkujący między Bugiem a Narwią, powiaty bielski, hajnowski i siemiatycki. Dosyć dużym skupiskiem dzisiaj jest też miasto wojewódzkie Białystok. W swoim czasie sporo ludzi tu migrowało. Bielsk to oczywiście siedziba Związku i chyba miejsce najbardziej aktywnej działalności Związku. Oczywiście w innych miastach też realizuje zadania i chcemy działać (W17).

Inny z badanych podkreśla, że świadomość pochodzenia i przynależności nie jest istotna przy zaliczaniu do danej grupy narodowej:

Sytuacja jest bardzo skomplikowana z tym, kogo zaliczać, a kogo nie. Tutaj duże znaczenie ma świadomość i to wszystko komplikuje, bo nie tylko środowisko ukraińskie postuluje przynależność tej ludności do swojej grupy. Głównie tak mówimy, w ten sposób, że Ukraińcami są ci ludzie ukraińskiego języka, tzn. ci, którzy pochodzą z tych miejscowości, gdzie rozmawiają w języku ukraińskim. Przynależności religijnej prawosławni, czyli to jakby za nich trochę robimy, bo uważamy, że oni do końca nie wiedzą o swoim pochodzeniu, ale tak naprawdę dla mnie nie ma tego znaczenia, czy ktoś sam się deklaruje (W25).

Drugim bardzo widocznym aspektem dyskursu polityczno-ideologicznego grupy oraz kierunkiem jej działań jest niezwykle silne przywiązanie do języka w oryginalnej formie gwarowej. W wielu artykułach mniejszości ukraińskiej w województwie podlaskim odnajdujemy podkreślenie wagi gwary ukraińskiej dla odrębności i tożsamości Ukraińców Podlasia. Podkreśla się potrzebę zachowania tej formy języka obok ukraińskiego literackiego oraz to, że każdy przedstawiciel grupy powinien znać swój język rodzimy, czyli gwarę. W artykule 
o godnym podkreślenia, ze względów ideologicznych, tytule Każdy prawostawny powinien znać swój język!, przedstawione są wszystkie argumenty przemawiające za potrzebą ocalenia języka rodzimego w formie gwary. Podkreśla się nie tylko jego wagę dla zachowania tradycji i tożsamości kulturowej, ale również błędne rozumienie „równania do polskiej normy" i zagrożenia asymilacji młodego pokolenia. Język jest również szczególnie ważny, jeżeli chodzi o zachowanie podlaskiego regionalizmu grupy oraz wyróżnianie się na tle reszty Ukraińców w Polsce. „Bez wątpienia więc, podstawowym obowiązkiem każdego Podlaszanina jest przekazanie ojczystej mowy swoim dzieciom, aby nie musiały one skarżyć się tak, jak jedna ze znajomych w liście: «wybacz, że piszę do Ciebie po polsku. Po prostu ten język znam lepiej. Próbowałam przyswoić sobie 'nasz język'», ale nie udaje mi się. Czasami myślę, że zostałam okradziona z pewnych umiejętności i to tak skutecznie, że nie ma od tego odwrotu». Nie jest bowiem prawda, że dziecko, które mówi po swojemu, będzie miało jakieś problemy z nauczeniem się niezbędnych w późniejszym życiu języka polskiego czy jakiegoś innego, i że języki te będą mu się mylié" (Hawryluk 2005: 46). W innym artykule Chichot Stalina nad orlańska gmina, czyli nazwy ,trochu po-naszomu, trochu po-czort-znaje-jakomu" autor zwraca uwagę na ogromne błędy językowe i zamieszanie, jakie powstało po wprowadzeniu dwujęzycznych nazw na terenie niektórych gmin województwa podlaskiego. Błędy historyczne i wchłonięcie ludności ukraińskiej przez ludność białoruską powodują dzisiaj wiele nieporozumień i błędów również językowych. Ludność tych terenów została opisana jako oszukana podwójnie: kiedyś wmówiono im, że są Białorusinami, a dzisiaj sami się oszukuja, przyjmując białoruską pisownię ukraińskich nazw. Autor zwraca uwagę na złe tłumaczenie nazw większości miejscowości oraz na fakt, że te dziwne nazwy „,...) to przeważnie hybrydy - dziwolagi powstałe z próby pogodzenia ukraińskiej fonetyki z białoruską ortografią" (Hawryluk 2011: 25). W podsumowaniu możemy przeczytać, że „ta białoruska narodowość, do której ukraińskojęzyczny prawosławny lud znad Bugu i Narwi przypisali Dmowski wespół ze Stalinem, jest właśnie taka sama jak te tablice - fasada jedynie na pokaz, bez wewnętrznej treści. A więc w istocie: Czort joho znaje szto/szczo" (Hawryluk 2011: 27). Również w prowadzonych przeze mnie badaniach wielokrotnie podkreślano wagę języka jako czynnika wyróżniającego i odróżniającego mniejszość ukraińską w województwie podlaskim od innych grup narodowych, a szczególnie od mniejszości białoruskiej.

W obliczu zmiany polityki silnej asymilacji przez większość polską postawa wobec nabywania cech kultury i tożsamości polskiej zmieniła się wśród dużej części ludności. Pojawia się bardzo liczna, jeżeli nie najliczniejsza obecnie, kategoria „Polaków prawosławnych”. Duża część ludności charakteryzująca się cechami lingwistyczno-kulturowymi ukraińskimi uległa asymilacji i dzisiaj uważają się za przedstawicieli narodu polskiego. W tym przypadku religia prawosławna odgrywa główną rolę w zakresie zachowania i funkcjonowania wśród danej zbiorowości więzi nie tylko religijnych, ale i etnicznych. Społeczności prawosławne wybierają taką autodeklarację przynależności etniczno-narodowej, ponieważ wydaje się ona najbardziej neutralna względem postrzeganych i doświadczanych sprzeczności typu narodowościowego (Sadowski 1991: 117).

Obecna sytuacja społeczno-polityczna sprawia, że wielu młodych działaczy ruchu ukraińskiego w regionie nie ma już dylematu Białorusin czy Ukrainiec, ale czują się związani 
z Polską. Wśród badanych studentów i licealistów związanych z mniejszością ukraińską w województwie podlaskim w ogromnej większości pojawiły się podwójne identyfikacje narodowe. Może to potwierdzać konkluzję o chęci przynależności młodych ludzi z jednej strony do kultury i narodowości ukraińskiej, a z drugiej strony chęci uczestniczenia w kulturze większości, w której funkcjonują na co dzień. Ten nurt, w moim badaniu, reprezentują takie wypowiedzi jak: „W najgłębszym przekonaniu czuję się Ukraińcem, lecz moja przynależność narodowa czy obywatelska to jest polska” (W37) czy „Powiem szczerze, że czuję się i Polka, i Ukrainka, że jestem przynależna do dwóch narodów, bo mam tą kulturę i korzenie ukraińskie, ale żyję, uczę się w Polsce, mówię po polsku częściej niż po ukraińsku”. Warto zaznaczyć, że w ten sposób wypowiadały się młode osoby aktywnie uczestniczące w kulturowej działalności mniejszości ukraińskiej w województwie podlaskim i w Związku Ukraińców Podlasia. „W takim najgłębszym to Polką, ale też poczuwam i identyfikuję się z narodem ukraińskim. Jestem przedstawicielem dwóch narodowości, tak to czuję" (W10).

Widać więc, że kształtowanie się tożsamości etniczno-narodowej na obszarze województwa podlaskiego nie przebiegało w próżni i w dużym stopniu zależało od polityki władz i większości, która potrafiła narzucić swój punkt widzenia mniejszości.

Współcześnie obszar województwa podlaskiego jest pograniczem, gdzie od wielu wieków współistniały i przenikały się różne języki, kultury i religie. Mamy tu do czynienia z językami i narodowościami: polską, białoruską, ukraińską, rosyjską czy litewską. Duża część mieszkańców uległa asymilacji przez kulturę dominująca, jednak ciągle bardzo wielu jest świadomych swojej odrębności i stara się pielęgnować, nie dopuścić do zaniku miejscowych dialektów i gwar. W wyniku zmian na przestrzeni wieków granic i zwierzchności państwowej nad tymi terenami zróżnicowanie to uległo jeszcze większym komplikacjom świadomościowo-narodowościowym. Bardzo trafnie zauważa to M. Koter (1995), który pisze, że „(...) na pograniczu białorusko-ukraińskim (także w granicach Polski) podobieństwa kulturowe pomiędzy tymi dwoma prawosławnymi narodami są tak silne, że ich formalne rozgraniczenie staje się niemożliwe. W rejonie Bielska Podlaskiego i Hajnówki zdarza się, że na skutek różnych sytuacji życiowych oraz poddania się odmiennej propagandzie politycznej, w obrębie tej samej rodziny ojciec jest «tutejszy», jeden syn uważa się za Białorusina, drugi za Ukraińca, a wyemancypowana córka deklaruje się jako Polka".

Rozwój demokracji w Polsce sprawił, że dzisiaj proces asymilacji (mimo że występuje i trwa nadal) jest odmienny od tego sprzed lat. Przedstawiciele mniejszości narodowych i etnicznych ciagle się asymiluja, ale tylko do pewnego stopnia. Ustalenie do jakiego powinno być przedmiotem autonomicznych i rozbudowanych badań socjologicznych. Demokracja pozwala bowiem poznać naród dominujący i uczestniczyć w jego strukturach, a jednocześnie przetrwać przy swojej kulturze, tożsamości i nie zrywać kontaktów z grupą pochodzenia. Używając słów A. Sadowskiego, można stwierdzić, że kultury tradycyjne, miejscowe, mniejszościowe nie są już wartościowane przez przedstawicieli mniejszości negatywnie. Przedstawiciele mniejszości, wchodząc do struktur demokratycznego społeczeństwa większościowego, korzystają z możliwości zdobycia awansu ekonomicznego, edukacyjnego i społecznego, jednocześnie zachowując własną tożsamość. Asymilacja mniejszości w warunkach demokracji zatrzymuje się więc najczęściej dopiero na etapie tożsamości (identyfikacji narodowej), przeważnie nie $\mathrm{z}$ powodu przymusu zewnętrznego, ale $\mathrm{z}$ powodu wyborów dokonywanych przez 
poszczególnych przedstawicieli mniejszości narodowych. Jednocześnie prawie powszechne uczestnictwo przedstawicieli mniejszości w strukturach społeczeństwa większościowego paradoksalnie wzmacnia ruchy mniejszościowe, czy to etniczne, czy narodowe. Ci, którzy osiągnęli wysoki status w strukturze społeczeństwa większościowego, jednocześnie zachowując tożsamość grupy mniejszościowej (pochodzenia), stają się bardzo często częścią elity, która działa skutecznie na rzecz mniejszości, jej rozwoju, a nawet rewitalizacji jej tradycji, kultury i rozpowszechniania się tożsamości (np. Ślązacy, Kaszubi czy nawet badana przeze mnie zbiorowość w województwie podlaskim).

Systemy autokratyczne budowały getta mniejszościom, nie dopuszczając przedstawicieli mniejszości do uczestnictwa w strukturze większości zarówno w odniesieniu do grup dominujących, jak i ich instytucji czy organizacji. Demokracja umożliwia całkowicie odmienny przebieg procesów asymilacji, które w takich warunkach mogą przeradzać się w proces integracji. Integrację traktuję jako jedną z podstawowych i możliwych dróg mniejszości narodowych i etnicznych w warunkach demokratyzacji życia społecznego. Działania i aktywność wielu przedstawicieli mniejszości oraz reprezentujących ich organizacji skupiają się właśnie na przeciwdziałaniu asymilacji oraz promowaniu integracji, która ma umożliwić równie funkcjonowanie w jednym społeczeństwie przy jednoczesnym zachowaniu własnej kultury. J. Szczepański definiuje: „Integracja jest naturalnym procesem wytwarzania się całości nie tylko poprzez tworzenie wspólnych instytucji formalnych, lecz przez wytwarzanie wspólnych wartości, wzorów działania, interesów i poglądów" (Szczepański 1961: 10).

W kontekście kontaktów międzykulturowych oraz relacji mniejszość-większość bardzo ciekawą koncepcję integracji przedstawia P. Boski. Reprezentuje on podejście, wedle którego czynnikiem warunkujących wystapienie jakiegokolwiek poziomu integracji społecznej jest pojawienie się innej, odmiennej, drugiej kultury. Autor wyróżnia pięć typów integracji społecznej:

1) Integracja jako pozytywne wartościowanie dwukulturowości - wyrażające się np. w czytelnictwie gazet, książek w innym języku, członkostwie w stowarzyszeniach, klubach sympatyzujących z inną kulturą czy w korzystaniu z produktów odmiennej kultury. Chodzi tu o poruszanie się w obu systemach kulturowych.

2) Integracja jako kompetencja dwujęzyczna/dwukulturowa - rozumiana przez autora jako np. pełna dwujęzyczność. Osoba zintegrowana w ten sposób miała od dzieciństwa kontakt z oboma językami, potrafi dostosowywać do wymagań sytuacyjnych i ról społecznych kody zachowań związane z dwiema kulturami.

3) Integracja rozumiana jako specjalizacja funkcjonalna - przykładem mogą być specjaliści, którzy są w stanie dobrze funkcjonować językowo w swojej specjalności w obcym kraju, jednak nie mają przyswojonych kompetencji na poziomie języka potocznego. Natomiast sprawne funkcjonowanie w danym, obcym kulturowo społeczeństwie wymaga nabycia nowych umiejętności kulturowych.

4) Integracja jako nowa jakość będąca fuzją elementów składowych - chodzi tu o pewnego rodzaju hybrydalność charakteryzującą na przykład osoby o podwójnej tożsamości, „Polish-American”, „Chinese-Australian”, „Kaszub-Polak”. Autor jako dalsze przykłady takiej integracji podaje synkretyzm religijny, językowy, kulinarny. 
5) Integracja jako autonomia psychologiczna wobec obu kultur wyjściowych - ten typ integracji zakłada etnorelatywizm, posiadanie kompetencji w zakresie funkcjonowania dwukulturowego, jednak jednoczesne nieprzejawianie bezwarunkowego przywiązania do nich i niekierowanie się uprzedzeniami wobec kultur obcych (Boski 2010).

Bardzo ciekawą z punktu widzenia mniejszości definicję integracji przedstawia M. Czerepaniak-Walczak. Definiując integrację, wskazuje na dwupodmiotową interakcję, która niejako dąży do synergii, wzmocnienia i zwiększenia wolności uczestniczenia i dostępu w sferze publicznej (Czerepaniak-Walczak 2005: 11). Autorka przestrzega, by nie mylić procesów inkluzji, włączania mniejszości, z procesami integracji, włączania się mniejszości. Inkluzja nie wymaga świadomego, samodzielnego i odpowiedzialnego udziału przedstawicieli grup mniejszościowych, są oni jej niejako poddawani odgórnie, nieświadomie. Autorka podsumowuje: „Kluczowym czynnikiem włączania się w życie zbiorowe jest zatem podmiotowy aktywizm i, będąca u jego źródła, świadomość osoby doświadczającej izolacji lub marginalizacji” (Czerepaniak-Walczak 2005: 11). Integracja w tym rozumieniu warunkowana jest samodzielnością podmiotów, zaangażowaniem we wspólne wartości i cele, stanowieniem wspólnych zasad, norm i dokonywaniem odpowiedzialnych wyborów.

Widoczne staje się, że integracja mniejszości i większości nie może nastąpić w każdych warunkach społecznych i politycznych, będąc jedynie wypadkową działań i zamierzeń. Potrzebne staje się konkretne podłoże kulturowe, odpowiednie warunki. Niemiecki badacz J. Fichter do warunków podstawowych, warunkujących rozpoczęcie procesu integracji i jego zaistnienie, zalicza spójność wartości znaczących, wśród których najistotniejszą rolę odgrywają: demokracja, wolność, postęp, braterstwo czy równość wobec prawa. Wedle autora występowanie tych wartości prowadzi do wspólnoty działań w systemie społecznym, która zbliża i prowadzi do integracji. Podsumowując, ludzie są zintegrowani, gdy cechują ich wspólne wartości i wynikające z nich czynności i kooperacja (Fichter za: Jacher 1976).

Mniejszość ma możliwość integracji z większością, ale tylko przy zaistnieniu specyficznych warunków. Integracja mniejszości zakłada utrzymanie tożsamości, jest wzajemna, dwustronna, opierająca się na narastaniu współdziałania między grupami, partnerstwa wynikającego z wspólnych wzorów i wartości. Mimo akcentowania wspólnoty umożliwia zachowanie tego, co odrębne. Idealnym podłożem dla wystąpienia prawidłowej integracji między mniejszością narodową czy etniczną a większością jest opisywany przez J. Smolicza „pluralizm wewnętrzny”. „Pluralizm wewnętrzny zakłada, że członkowie grup etnicznych konstruując systemy społeczno-kulturowe, mają możliwość czerpania z więcej niż jednego źródła etnicznego" (Smolicz 1990: 114). Ten typ pluralizmu skupia się na kontaktach, interakcjach kulturowych dwu lub więcej grup, zbiorowości, dając każdemu możliwość internalizacji wartości kulturowych wszystkich grup. Jednocześnie nie wpycha w pułapkę fuzji kulturowej, zwracając uwagę na wymianę międzykulturową zachodzącą w relacjach społecznych przedstawicieli różnych grup narodowych i etnicznych. Słabo wykształcona integracja lub jej brak powoduje, że członkowie mniejszości narodowej czy etnicznej i większości nie tworzą wspólnoty, lecz żyją „obok siebie”. Natomiast zaistnienie i budowa integracji tworzy społeczność połączona, opartą na wspólnocie wartości demokratycznych i wolnościowych, wzorów i działań, ludzi żyjących i będących „ze sobą” mimo dzielących ich różnic. 
Trudno dzisiaj, w sposób jednoznaczny, mówić o istnieniu silnej integracji (w rozumieniu przedstawionym powyżej) w jakimkolwiek z regionów Polski, w którym występują mniejszości narodowe i etnicznej. Co nie oznacza, że same mniejszości nie podejmują aktywnych działań na rzecz integracji z większością oraz bycia „razem”, a nie funkcjonowania osobno. Jako przykład może posłużyć mniejszość ukraińska w województwie podlaskim, która tworząc własną organizację, za jej najważniejsze działania uznała:

1) „Organizowanie przedsięwzięć kulturalnych, naukowych, wychowawczych, rozrywkowych.

2) Działalność wydawniczą oraz tworzenie materiałów w technice audiowizualnej.

3) Współdziałanie $\mathrm{z}$ władzami oświatowymi w zakresie organizowania szkolnictwa ukraińskiego i jego funkcjonowania, organizowania nauki języka ukraińskiego w szkołach oraz innych form nauki tego języka.

4) Organizowanie zespołów artystycznych oraz środków krzewienia i popularyzacji kultury i sztuki ukraińskiej.

5) Inspirowanie powoływania ośrodków naukowych zajmujących się badaniami naukowymi dotyczącymi społeczności ukraińskiej.

6) Współdziałanie z radiem i telewizją w zakresie przygotowania i realizacji audycji o tematyce ukraińskiej.

7) Prowadzenie działalności wychowawczej z dziećmi i młodzieżą, organizowanie imprez, kolonii.

8) Współdziałanie z odpowiednimi instytucjami w zakresie opieki nad zabytkami i innymi obiektami kultury ukraińskiej.

9) Podejmowanie odpowiednich działań interwencyjnych w celu ochrony praw społeczności ukraińskiej oraz praw jednostki, a w szczególności praw członków Związku” (Statut Związku Ukraińców Podlasia 1992, paragraf 9).

Powyższy fragment statutu organizacji sugeruje, że w większości podejmowanych działań dąży ona do zachowania i rozwoju własnej kultury, ale przy wsparciu i współdziałaniu ze strony większości. Korzystając z warunków demokratyzacji życia społecznego i politycznego, mniejszość ukraińska w województwie podjęła wiele działań mających na celu zahamowanie asymilacji oraz większą integrację większości z innymi mniejszościami regionu. Podejmowana aktywność nie ogranicza się już dzisiaj tylko do aspektów promowania kultury, ale obejmuje również edukację, politykę na szczeblu samorządowym oraz media.

Cyklicznie organizowanych jest wiele imprez kulturalnych łączących miejscowy folklor i tradycję z ogólnie pojmowaną kulturą mniejszościową i ukraińską. Największą jest Festiwal Kultury Ukraińskiej na Podlasiu „Podlaska Jesień” odbywający się nie tylko w Bielsku Podlaskim, ale również m.in. w Białymstoku, Siemiatyczach czy Czeremsze. Równie popularną i znaną w regionie imprezą kulturalno-folkową organizowaną przez ZUP jest „Na Iwana, na Kupała” organizowaną nad zalewem w Dubiczach Cerkiewnych. Impreza ma już kilkunastoletnią tradycję, pierwszy raz odbyła się bowiem w 1996 roku nad Narwią. Nad zalewem Bachmaty w Dubiczach Cerkiewnych odbywa się od 1998 roku. 
Bardzo ważną częścią realizacji celów, stawianych w statucie organizacji, jest wydawanie przez ZUP periodyku „Nad Buhom i Narwoju”. Publikowane w nim artykuły dotyczą życia kulturowego, religijnego i politycznego miejscowej ludności pochodzenia ukraińskiego. W piśmie przedstawiane są zarówno wątki historyczne, jak i aktualne wydarzenia dotyczące ludności ukraińskojęzycznej w województwie podlaskim.

Związek Ukraińców Podlasia od początków swojej działalności dążył do uruchomienia ukraińskojęzycznego programu telewizyjnego, który relacjonowałby istotne fakty i wydarzenia z życia miejscowej ludności oraz przedstawiał punkt widzenia i pomagał w szerzeniu świadomości i tożsamości wśród mieszkańców województwa podlaskiego posługujących się gwarąjęzyka ukraińskiego. Program miał być nadawany w języku mniejszości z jednoczesnym tłumaczeniem na język polski w postaci napisów (Ryżyk, Kuprianowicz 1992: 31). Program zaczął się ukazywać od 1995 roku, jeszcze w ramach Warszawskiego Ośrodka Telewizji. Po powstaniu Białostockiego Ośrodka Telewizji program o nazwie „Ukraiński Przegląd” ukazuje się w ramach bloku tematycznego dotyczącego wszystkich mniejszości województwa o nazwie „Sami o sobie”. Program relacjonuje wydarzenia kulturalne społeczności, bieżąca działalność ZUP, prezentowane są felietony dotyczące miejscowej tradycji, religii, folkloru.

Przedstawiciele mniejszości ukraińskiej w województwie podlaskim prowadzą od 1991 roku w Radiu Białystok program „Ukraińska Dumka”, który emitowany jest trzy razy w tygodniu. Od 2009 roku w regionalnym radiu Orthodoxia emitowana jest raz w tygodniu audycja w języku ukraińskim przygotowywana i prowadzona przez osoby związane z mniejszością ukraińską w województwie podlaskim.

Warto zaznaczyć, że ostatnie lata przyniosły również mniejszości ukraińskiej w województwie podlaskim spore sukcesy na gruncie narodowej edukacji. Zarówno w Bielsku Podlaskim, jak i w Białymstoku powstały klasy w szkołach podstawowych i średnich umożliwiające naukę języka ukraińskiego i poznawanie tej kultury. W Bielsku Podlaskim powstało przedszkole z nauką języka ukraińskiego, gdzie dodatkowo realizowany jest projekt „Do źródeł”. Polega on na tym, że dzieci na nietypowych zajęciach poznają ukraińskie kolędy, język, zwyczaje i obrzędy rocznego cyklu kalendarzowego. W projekcie bierze udział 114 dzieci, czyli ponad połowa uczęszczająca do Przedszkola nr 9 w Bielsku Podlaskim.

Pod patronatem ZUP działa kilka amatorskich zespołów artystycznych, do których należą dzieci i młodzież ze szkół oraz przedszkola, gdzie naucza się języka ukraińskiego. Zespoły te zajmują się głównie pielęgnacją i propagowaniem miejscowego folkloru i związanymi z nim piosenkami czy obrzędami. Warto wymienić zespoły: „Rodyna” z Dubiażyna, młodzieżowy „Ranok” z Bielska Podlaskiego, „Strumok” z Dubicz Cerkiewnych, „Hiłoczkę” z Czeremchy, „Tyrsę" z Kleszczel.

Przedstawiciele i działacze ZUP, również w ostatnich latach, rozpoczęli działalność nie tylko kulturowo-instytucjonalną, ale również polityczną. Ta aktywność znalazła odzwierciedlenie w życiu politycznym regionu. Przedstawiciele Związku Ukraińców Podlasia osiagali i osiaggają sukcesy w wyborach samorządowych, zasiadając $w$ radach miast i gmin oraz pełniąc różne funkcje samorządowe - wójta, zastępcy burmistrza, przewodniczącego rady miasta w miejscowościach położonych głównie w południowej części województwa podlaskiego.

Powyższe działania mniejszości świadczą o tym, że w czasach demokracji najczęstszym sposobem integracji mniejszości z większością jest instytucjonalizacja zarówno jej struktur, 
jak i działan. Tworzone są specjalne instytucje reprezentujące mniejszość, organizujące jej działania czy w końcu edukujące młodych przedstawicieli mniejszości, a wiele osób ulega tzw. profesjonalizacji działań na polu etniczno-narodowym.

Na tle tych działan ciekawie wypadają badania dotyczące liczebności mniejszości narodowych i etnicznych w województwie podlaskim. Ludność województwa (oprócz narodowości polskiej) najliczniej identyfikowała się z narodowością białoruską, litewską i ukraińską. Według danych spisu powszechnego z 2011 roku liczebność mniejszości białoruskiej w województwie podlaskim wyniosła 38,3 tys. osób wobec 46,4 tys. osób w 2002 r., przy czym narodowość białoruską jako jedyną wskazało 26,7 tys. badanych, zaś występującą razem z polską 11,0 tys. Deklaracji litewskich było 4,7 tys. wobec 5,2 tys. w 2002 r., w tym narodowość litewską występującą z polską zadeklarowało 0,8 tys. respondentów (http://www.stat.gov.pl/ bialystok/69_1078_PLK_HTML.htm). Mniejszość ukraińska w województwie podlaskim jest jedyną grupa, w której zwiększyła się liczebność świadomych członków w ostatnich latach. W 2011 roku z narodowością ukraińską utożsamiało się 2,2 tys. osób, czyli o 0,8 tys. więcej niż podczas poprzedniego spisu, a wśród nich 0,8 tys. osób zadeklarowało przynależność do narodu polskiego i ukraińskiego (http://www.stat.gov.pl/bialystok/69_1078_PLK_HTML.htm).

Wyniki świadczą o tym, że „najmłodsza” oficjalnie działająca na terenie województwa mniejszość narodowa w ostatnich latach podjęła intensywne działania i trud odbudowy swojej świadomości i jej szerzenia wśród ludności posługującej się gwarą ukraińską, co przyniosło widoczne rezultaty.

Trzecim możliwym kierunkiem aktywności mniejszości w warunkach demokracji i kontaktów z grupą dominującą jest autonomizacja, czyli „,prawo do samodzielnego rozstrzygania spraw wewnętrznych danej zbiorowości, dotyczące narodu, miasta, instytucji itp.; samostanowienie" (Słownik Języka Polskiego 1988: 101). Najczęściej do autonomizacji częściowej lub całkowitej grupy etnicznej czy mniejszości dochodzi w dwóch przypadkach. Jednym z nich jest sytuacja, gdy grupa etniczna czy regionalna nabywa świadomość odrębności, wśród jej członków pojawia się tożsamość etniczna czy narodowa, a sama grupa i jej przedstawiciele mają ambicje, by otrzymać miano mniejszości narodowej lub nawet odrębnego narodu.

Należy silnie podkreślić, że uznanie danej grupy za naród albo choćby mniejszość narodową zmienia całkowicie jej status prawny i umożliwia choćby częściową autonomizację. Mniejszościom narodowym przysługują nie tylko prawa kulturalne, ale również prawa edukacyjne czy polityczne. W tym przypadku autonomizacja może dotyczyć uzyskania praw i pewnej niezależności od danego państwa i rządzącej nim grupy dominującej, ale również może dotyczyć autonomizacji części danej mniejszości narodowej, jeśli uzna ona, że ma wyraźne cechy dystynktywne wyróżniające ją względem pozostałej części danej mniejszości narodowej. Jako przykład pierwszej sytuacji może służyć trwający już wiele lat konflikt o uznanie śląskiej grupy regionalnej za mniejszość narodową i przyznanie jej praw przysługujących mniejszościom narodowym. Ruch Autonomii Śląską powołał w latach dziewięćdziesiątych XX wieku Związek Ludności Narodowości Śląskiej, który domaga się uznania Górnoślązaków za mniejszość narodową, przyznania im praw i przywilejów mniejszości, a w przyszłości uzyskania szerokiej autonomii. Jednak do dzisiaj organizacje nie są oficjalnie zarejestrowane i uznane przez prawo polskie. Innym przykładem dotyczącym drugiej z opisywanych sytuacji może być stanowisko i działania, które podjęli przedstawiciele mniejszości 
ukraińskiej w województwie podlaskim. Związek Ukraińców Podlasia działał początkowo w ramach ogólnopolskiej organizacji mniejszości ukraińskiej - Związku Ukraińców w Polsce i był oddziałem organizacji.

Jednak bardzo szybko, bo już 22 marca 1992 roku, nastąpiło oderwanie i usamodzielnienie się organizacji - powstał Związek Ukraińców Podlasia. Separacja nastąpiła pod wpływem sprzeczności i kształtowania odmiennych celów i działań organizacji w kontekście lingwistyki, etnografii oraz wyznania (Misiejuk 2004). Ludność województwa podlaskiego związana z gwarami ukraińskimi to przedstawiciele prawosławia, natomiast pozostali Ukraińcy w Polsce to głównie wyznawcy kościoła greckokatolickiego. Odrębność mniejszości w województwie podlaskim stała się w tym momencie widoczna nie tylko ze względów kulturowych, ale również organizacyjnych. Związek Ukraińców Podlasia uzyskał w praktyce niezależność i możliwość autonomicznych działań w stosunku do ZUwP. Przyjęty statut stanowi, że Związek Ukraińców Podlasia jest organizacją służącą społeczności ukraińskiej Podlasia, a na celu ma reprezentowanie jej interesów i ich realizację. Dodatkowo za cel organizacja stawia sobie rozwój ukraińskiej świadomości narodowej wśród ludności posługującej się gwarą ukraińską oraz zachowanie i rozwój miejscowej kultury ukraińskiej (Statut Związku Ukraińców Podlasia 1992, paragraf 1 i 8). Główna siedziba Związku Ukraińców Podlasia znajduje się w Bielsku Podlaskim, natomiast związek wykształcił i powołał swoje oddziały również w Białymstoku, Hajnówce oraz Orli.

Główne stawiane i realizowane przez organizację cele to:

1) Przedstawianie władzom i instytucjom państwowym oraz społecznym stanowiska społeczności ukraińskiej w sprawach politycznych i społecznych oraz przedstawianie potrzeb tej społeczności.

2) Przedstawienie ukraińskojęzycznej społeczności Podlasia na gruncie nowej tradycji, kultury i prawosławia, kształtowanie jej świadomości narodowej i patriotycznych postaw.

3) Zapewnienie ścisłych więzi z Ukrainą oraz ukraińską diasporą w świecie.

4) Działanie na rzecz rozwoju kultury ukraińskiej oraz pielęgnowanie i ochrona zabytków kultury i miejsc pamięci narodowej.

5) Pielęgnowanie języka ukraińskiego i upowszechnianie jego nauczania.

6) Krzewienie humanistycznych wartości w życiu społecznym, idei równości, wzajemnego zrozumienia i poznawania, godności narodowej i osobistej jednostki.

7) Działanie na rzecz zbliżenia polsko-ukraińskiego i ukraińsko-białoruskiego oraz kształtowania dobrosąsiedzkich stosunków i wzajemnego szacunku między narodami (Statut Związku Ukraińców Podlasia 1992, paragraf 8).

Związek Ukraińców Podlasia uzyskał więc bardzo dużą autonomię i niezależność w zakresie swych działań w stosunku do Związku Ukraińców w Polsce. Opiera się na miejscowych tradycjach, historii i ogólnie aktualnych realiach. Grupa ta buduje swoją siłę i tożsamość, wykorzystując miejscową tradycję i folklor oraz ideę „małej, prywatnej ojczyzny”. W związku $\mathrm{z}$ tym $\mathrm{w}$ ich programie oraz działaniach widać wiele autonomicznych i odgraniczających posunięć. Badania potwierdzają świadomość różnic wobec pozostałych Ukraińców w Polsce, ale jednocześnie działacze Związku Ukraińców Podlasia reprezentują pragmatyczne stanowisko 
w sprawie szerszej autonomii, zdając sobie sprawę z małej liczebności ruchu oraz negatywnych konsekwencji organizacyjnych, które takie oderwanie by przyniosło. „Różnimy się wieloma rzeczami i cechami w stosunku do pozostałych Ukraińców w Polsce. No ale niestety z powodu niskiej świadomości narodowej, tutaj u nas w regionie, to jak dla mnie to uzyskanie takiej autonomii jest aktualnie zupełnie nierealne. Chodzi mi tutaj o jakąś autonomię, ale też samodzielne nawet pielęgnowanie kultury lokalnej nie jest możliwe, bo ruch jest ciągle za słaby i mało ciągle w pełni świadomych członków" (W4).

W zakończeniu można postawić pytanie o to, jakie są w warunkach demokratycznych granice osiągania autonomii przez mniejszości narodowe w obrębie poszczególnych państw. W warunkach kiedy występują duże i skupione terytorialnie mniejszości narodowe o ukształtowanej i silnej tożsamości narodowej, zazwyczaj dążą one do uzyskania szerokiej autonomii prawnej i politycznej w ramach danego organizmu politycznego lub nawet do trwałego i całkowitego wyodrębnienia się i utworzenia własnego państwa. W tym przypadku często wybuchają ostre konflikty narodowe i etniczne, ale nie są one powodowane obroną tożsamości mniejszości czy jej zachwianiem i słabością. Są powodowane tym, że grupa mniejszościowa czuje się silna, dobrze zintegrowana, a jako mniejszość może mieć poparcie państwa macierzystego (patronackiego). W takiej sytuacji bardzo często pojawia się idea całkowitej autonomii, oderwania od państwa innego narodu i utworzenia własnego, w którym dana grupa będzie większością. Za przykład takich ruchów mogą służyć Albańczycy w Kosowie czy Serbowie w Chorwacji. Dobrym przykładem silnego ruchu mniejszościowego w danym państwie, który uzyskał bardzo dużą autonomię mogą być Baskowie w Hiszpanii.

Uwzględniając perspektywę konfliktową, można stwierdzić, że granicami osiagania autonomii przez mniejszości narodowe w obrębie poszczególnych państw są: zachowanie integralności terytorialnej państwa narodowego większości oraz troska o to, aby nie wystąpiło wśród większości narodowej poczucie zagrożenia utraty integralności terytorialnej i politycznej. Wydaje się więc, że optymalnym wyjściem jest konstruowanie nowych jakościowo form współpracy pomiędzy mniejszościami i większością w obrębie państw demokratycznych. W obecnych warunkach byłoby to konstruowanie w obrębie państwa społeczeństwa pluralistycznego.

\section{BIBLIOGRAFIA}

Badania jakościowe własne, przeprowadzone od 01.05.2011 do 31.06.2012, na próbie 54 osób deklarujących etniczne pochodzenie ukraińskie i zamieszkujących województwo podlaskie, dokładne wyniki w pracy doktorskiej Procesy tworzenia się (konstruowania) małego narodu (kulturowego) na przykładzie mniejszości ukraińskiej w województwie podlaskim oraz powstającej na jej podstawie monografii.

Barwiński, Marek. 2011. Ukraińcy na Podlasiu - geneza, kontrowersje, współczesność, w: J. Dzieciuchowicz (red.), Acta Universitatis Lodziensis Folia Geographica Socio-Oeconomica nr 11, Łódź: Wydawnictwo Uniwersytetu Łódzkiego.

Boski, Paweł. 2008. Wielokulturowość i psychologia dwukulturowej integracji, w: Hanna Mamzer (red.), Czy klęska wielokulturowości?, Poznań: Wydawnictwo Fundacji Humaniora. 
Kierunki aktywności mniejszości narodowych w warunkach demokracji...

Boski, Paweł. 2009, Kulturowe ramy zachowań społecznych, Warszawa: Wydawnictwo Naukowe PWN.

Czerepaniak-Walczak, Maria 2005. Przesłanki integracji społecznej i kulturowej-pułapki izonomii, Szczecin: In Plus

Dawidziuk, Andrzej. 2005. O sztuce czynienia zamieszania $w$ sprawach prostych, „Nad Buhom i Narwoju" 1: 2.

Filimoniuk, Ludmiła. 2005. Co przyniesie przyszłość, „Nad Buhom i Narwoju” 3: 12.

Hawryluk, Jerzy. 2005. Każdy prawosławny powinien znać swój język, „Nad Buhom i Narwoju" 4: 36.

Hawryluk, Jerzy. 2011. Chichot Stalina nad orlańska gmina czyli nazwy "troche po-naszomu, troche po-czort-znaje-jakomu”, „Nad Buhom i Narwoju” 6: 25.

Hawryluk, Jerzy. 2012. A kuolki to je naszoho narodu na Pudlaszu?!, „Nad Buhom i Narwoju" 1: 9.

Jacher, Włodzimierz. 1976. Zagadnienia integracji systemu społecznego: studium z zakresu teorii socjologii, Warszawa: Państwowe Wydawnictwo Naukowe.

Kłoskowska, Antonina. 1992a. Tożsamość i identyfikacja narodowa w perspektywie historycznej i psychologicznej, „Kultura i Społeczeństwo” 1: 131-141.

Kłoskowska, Antonina. 1992b. Konwersja narodowa i narodowe kultury. Studium przypadku, „Kultura i Społeczeństwo” 4: 5-20

Koter. Marek. 1995. Ludność pogranicza - próba klasyfikacji genetycznej, „Acta Universitatis Lodziensis. Folia Geographica" 20.

Kubiak, Hieronim. 2005. Asymilacja, w: Encyklopedia socjologii, Warszawa: Oficyna Naukowa.

Kuprianowicz Grzegorz, Ryżyk Eugeniusz. 1992. Kronika podlaska, „Nad Bohom i Narwoju". 2: 30-31,

Misiejuk, Dorota. 2004. Tożsamość ukraińska w Polsce: odtwarzanie czy tworzenie? Uwagi o kreacji tożsamości mniejszościowej, w: Zenon Jasiński i Tadeusz Lewowicki (red.), Kultura mniejszości narodowych i grup etnicznych w Europie, Opole: Uniwersytet w Opolu.

Nikitorowicz Andrzej. 2014. Ukraińcy Podlasia. Dylematy tożsamościowe, Zakład Wydawniczy Nomos Kraków.

Nowicka, Ewa. 1990. Swoi i obcy, Warszawa: Uniwersytet Warszawski.

Obrębski, Józef. 2005. Socjologia powstajacych narodów, w: Dzisiejsi ludzie Polesia i inne eseje, Warszawa: Wydawnictwo IFiS PAN.

Posern-Zieliński, Aleksander. 1999. Akulturacja i asymilacja-dwie strony procesu etnicznej zmiany w ujęciu antropologii i etnohistorii, w: Witold Mloik i Robert Traba (red.) Procesy akulturacji/asymilacji na pograniczu polsko-niemieckim w XIX i XX wieku, Poznań: Instytut Historii UAM .

Raport Narodowy Spis Powszechny 2002 roku dla województwa podlaskiego, http://www. stat.gov.pl/bialystok/69_140_PLK_HTML.htm [15.05.2013].

Sadowski, Andrzej. 1991. Narody wielkie i małe. Białorusini w Polsce, Kraków: Instytut Religioznawstwa, Uniwersytet Jagielloński.

Sadowski, Andrzej. 1995. Pogranicze polsko-białoruskie. Tożsamość mieszkańców, Białystok: Wydawnictwo Trans Humana. 
Słownik języka polskiego. 1988. Mirosław Szymczak (red.), Warszawa: PWN.

Smolicz, Jerzy J. 1990. Kultura i nauczanie w społeczeństwie wieloetnicznym, Warszawa: PWN.

Statut Związku Ukraińców Podlasia. 1992. Bielsk Podlaski.

Szczepański, Jan. 1961. Socjologia. Rozwój problematyki i metod, Warszawa: PWN.

THE DIRECTIONS OF ACTIVITIES OF NATIONAL MINORITY IN TERMS OF DEMOCRACY

ON THE EXAMPLE OF THE UKRAINIAN MINORITY IN PODLASKIE VOIVODESHIP

The purpose of the article is to describe, based on own empirical examinations, the activities and actions of a minority group which under the conditions of a democracy is trying to revitalize and revive their own culture and national awareness. Ukrainians in Podlasie Voivodeship are an autochthonous minority group which within the past 20 years has been making attempts at the reconstruction of its identity. Only 25 years ago all Orthodox residents of the province were regarded as representatives of the Belarussian minority; today this image has become much more complicated and the Ukrainian minority in the voivodeship is the only one recording an increasing number of conscious members.

Key words: national minority, ethnic minority, reviving national awareness, assimilation, integration, gaining autonomy 